\title{
PENGEMBANGAN METODE PERMAINAN DAN LAGU DI PAUD/TK RINJANI UNIVERSITAS MATARAM
}

\author{
Atri Dewi Azis $\left.{ }^{1 *}\right)$, Kamaluddin $^{1}$, Khusnul Khotimah $^{1}$ \\ ${ }^{1}$ Program Studi Pendidikan Bahasa Inggris, Fakultas Keguruan dan IImu Pendidikan, \\ Universitas Mataram \\ ${ }^{*}$ Korespondensi: atridewi75@unram.ac.id
}

Diterima 10 November 2020 / Disetujui 9 Desember 2020

\begin{abstract}
ABSTRAK
Permasalahan yang sering dialami oleh lembaga pendidikan anak usia dini adalah kurangnya sarana dan prasarana permainan yang edukatif, sementara anak-anak usia dini sangat senang jika diajak bermain. Untuk itu, tujuan kegiatan ini adalah melakukan pengembangan metode permainan dan lagu bagi anak PAUD/TK Rinjani Universitas Mataram. Metode kegiatan yang dilakukan adalah metode sosial partisipatif yang berorientasi kepada peran aktif mitra secara langsung dalam berbagai proses kegiatan, mulai dari proses perencanaan, pelaksanaan sampai dengan evaluasi kegiatan. Beberapa jenis kegiatan yang akan dikerjakan, antara lain melakukan pendampingan kepada anak-anak PAUD/TK melalui permainan-permainan yang mendidik dan menyenangkan, pemberian hadiah kepada anak-anak, menerapkan sekolah alam sebagai media untuk menghilangkan kejenuhan sekaligus sebagai wahana bermain, belajar, dan pengembangan kognitif bagi anak-anak PAUD/TK.
\end{abstract}

Kata kunci: anak usia dini, edukatif , kognitif, lagu, permainan

\section{PENDAHULUAN}

Perkembangan

berbahasa berkaitan erat dengan perkembangan berbicara. Semakin mampu orang berbicara, semakin kaya kemampuan berbahasanya. Semakin kaya kemampuan berbahasa membuat anak semakin percaya diri untuk berbicara. Pada masa pra sekolah kemampuan bahasa berkembang pesat seiring dengan kebutuhan untuk bersosialisasi dan rasa ingin tahu anak (Bjorklund, 2005). Bahkan mereka juga lebih mudah untuk belajar bahasa selain bahasa ibu, dibandingkan dengan orang dewasa (Santrock, 2007). Belajar bahasa penting diberikan. baik bahasa ibu, bahasa daerah, bahasa Indonesia, dan bahasa asing termasuk bahasa Inggris. Berlatih mengaplikasikan bahasa Inggris, seperti cara mengucapkan suatu kata atau kalimat dan kapan kalimat itu harus digunakan setidaknya akan lebih membantu anak dalam memahami fungsi bahasa secara lebih mendalam

Pada peringatan hari Pendidikan Nasional tanggal 2 Mei 2013, Menteri Pendidikan dan Kebudayaan Republik Indonesia, Mohammad Nuh, telah mencanangkan generasi emas sebagai tema peringatan Hardiknas pada tahun tersebut. Pencanangan generasi emas perlu ditindaklanjuti dengan mengenalkan bahasa Inggris sejak dini, karena bahasa Inggris merupakan bahasa internasional. Penguasaan bahasa Inggris merupakan kendaraan untuk berkiprah secara global dan mendunia. Dengan mengenalkan 
bahasa Inggris sedini mungkin, berarti membekali para insan bangsa untuk dapat mengarungi dunia ilmu pengetahuan dan teknologi secara leluasa, namun tetap mengutamakan budaya nasional.

Pembelajaran bahasa Inggris bagi anak usia dini sejalan dengan pendapat beberapa ahli, mereka mengatakan bahwa sebenarnya kemampuan anak usia dini lebih cemerlang dari pada apa yang dibayangkan oleh orang dewasa. Mereka dapat melakukan penjumlahan sebelum mereka mampu berhitung. Mereka dapat mengerti seratus kata sebelum mereka mampu berbicara dengan lancer,bahkan pada usia tiga bulan daya ingat mereka sangat tinggi, lebih tinggi dari apa yang dibayangkan oleh orang dewasa (Cole \& Cole, 2001). Pandangan ini menepis asumsi bahwa upaya mengenalkan bahasa asing kepada anak usia dini akan mengganggu perkembangan bahasanya.

Dengan demikian mengajarkan bahasa Inggris sebagai bahasa asing lebih tepat bila dilakukan sedini mungkin. Periode kritis/sensitif untuk belajar bahasa adalah pada anak usia dini, dimana fleksibilitas otak masih sangat baik. Perkembangan kemampuan berbahasa akan mendasari kemampuan membaca. Semakin kaya penguasaan kosakata yang dimiliki, maka semakin mudah anak memahami tulisan yang pada akhirnya semakin lancar kemampuan anak membaca.

Mengajari anak-anak berbahasa Inggris membutuhkan penggunaan teknik tertentu. Sebagai tenaga pendidik perlu mengambil pendekatan yang interaktif dan menyenangkan untuk belajar bahasa. Seorang anak berusia antara 4 hingga 7 tahun masih belajar tentang interaksi sosial dan nilai-nilai sosial. Ini adalah waktu yang tepat untuk membiasakan mereka belajar bahasa Inggris. Pada usia ini otak mereka sangat lunak pada tahap ini dan kata-kata baru akan sepenuhnya tertanam dalam ingatan mereka (Handayani, 2019).
Ada banyak media belajar yang dapat guru gunakan ketika mereka mengajari anak-anak berbahasa Inggris, diantaranya dengan bermain atau dengan bernyanyi. Belajar Bahasa Inggris dengan bermain dan bernyanyi adalah cara tercepat untuk belajar bahasa karena bersenang-senang membuat seluruh proses belajar tidak takan membosankan.

Dalam ranah pendidikan, istilah bermain sambil belajar, belajar seraya bermain tidak asing untuk didengar. Anak dan permainan merupakan dua hal yang hampir tidak dapat dipisahkan satu sama lain. Menurut Langeveld (1980) permainan merupakan kesibukan yang paling banyak dilakukan oleh dunia anak yang sangat menyenangkan dan menggembirakan. Permainan adalah suatu perbuatan yang mengandung keasyikan dan dilakukan atas kehendak sendiri, bebas tanpa paksaan dengan bertujuan untuk memperoleh kesenangan pada waktu mengadakan kegiatan tersebut. Permainan cukup penting bagi perkembangan jiwa anak. Oleh karena itu, perlu kiranya bagi anak-anak untuk diberi kesempatan dan sarana di dalam kegiatan belajarnya dengan berbagai variasi permainan (Ahmadi, 1991). Permainan juga bisa sebagai salah satu bentuk aktivitas sosial yang dominan pada masa awal anakanak. Sebab, anak-anak menghabiskan lebih banyak waktunya di luar rumah untuk bermain dengan teman-temannya dibandingkan terlibat dengan aktivitas lainnya. Karena itu, permainan bagi anakanak adalah suatu bentuk aktivitas yang menyenangkan yang dilakukan semata-mata untuk aktivitas itu sendiri, bukan karena ingin memperoleh suatu hasil dari aktivitas tersebut. Hal ini disebabkan karena bagi anak-anak proses melakukan sesuatu lebih menarik daripada hasil yang akan didapatkannya (Aprianti, 2017).

Belajar bahasa inggris dengan cara yang menyenangkan bisa juga diajarkan melalui lagu. Lagu merupakan sarana yang 
sangat efektif untuk membantu proses belajar bahasa Inggris karena mampu memotivasi siswa selama mengikuti pembelajaran bahasa Inggris. Dapat pula dikatakan bahwa lagu merupakan bagian yang penting dari pembelajaran bahasa Inggris karena lagu menjadikan para siswa lebih sensitif terhadap bunyi dan mempelajari bahasa

Ketika anak sudah tertarik untuk melakukan pembelajaran dengan menggunakan metode bernyanyi, maka anak akan mudah dalam mengikuti setiap tahapan pembelajaran dan anak-anak akan mudah untuk menguasai dan menghafal kosakata bahasa Inggris. Dengan menyanyi menirukan suara guru di depan kelas bersama teman-temannya, anak akan semakin senang terhadap apa yang dipelajarinya, terutama di lingkungan sekolah. Dengan demikian bernyanyi merupakan suatu kegiatan yang sangat disukai oleh anak-anak. Secara umum menyanyi bagi anak usia dini lebih berfungsi sebagai aktivitas bermain daripada aktivitas pembelajaran atau penyampaian pesan. Menyanyi dapat memberikan kebahagiaan dan kegembiraan, sehingga dapat mendorong anak untuk belajar lebih giat.

Berdasarkan uraian di atas, maka dapat diidentifikasi bahwa penting mengajarkan bahasa Inggis sejak usia usia dini, namun permasalahannya terletak pada kompetensi guru yang masih minim pengalaman mengajar bahasa Inggris kepada anak-anak. Di samping itu, guru yang memiliki latar belakang pendidikan bahasa Inggris tidak ada. Oleh sebab itu, Tim pengabdi ingin membantu untuk melatih Ibu Guru TK/PAUD Rinjani Unram agar dapat memberikan pelajaran bahasa Inggris kepada anak-anak supaya tidak tertinggal dari taman kanak-kanak yang lain. Tujuannya lainnya adalah agar siswa dan siswi TK/PAUD Rinjani Unram dapat diperkenalkan bahasa Inggris dari usia dini agar kedepannya mereka menyukai pelajaran bahasa Inggris.

\section{METODE KEGIATAN}

\section{A. Tempat dan Waktu}

Pelaksanaan kegiatan pengabdian pada masyarakat ini telah dilaksanakan di TK/PAUD Rinjani Unram Jalan Pendidikan No. 37 Dasan Agung Mataram. Kegiatan ini meliputi tahap persiapan dan tahap pelaksanaan. Tahap persiapan meliputi perizinan tempat kegiatan pendampingan dalam pengembangan permainan dan lagu bahasa Inggris, perjanjian atau melakukan kontrak kerjasama dengan mitra, persiapan tempat untuk kegiatan pelatihan dan persiapan sarana prasarana yang digunakan untuk menunjang kegiatan pengajaran dan pelatihan. Tahap Pelaksanaan, meliputi ceramah, diskusi, demonstarasi dan praktek. Peserta kegiatan adalah guru TK/PAUD Rinjani Unram berjumlah 17 orang.

\section{B. Khalayak Sasaran}

Sasaran pelaksanaan program kemitraan ini adalah Guru Sekolah TK/PAUD yang berlokasi di Jalan Pendidikan No. 37 Dasan Agung Kota Mataram.

\section{Metode Pendekatan}

Metode pendekatan yang digunakan adalah metode partisipatif yang berorientasi kepada upaya peran serta mitra secara langsung dalam berbagai proses dan tahap pelaksanaan kegiatan, mulai dari proses perencanaan, pelaksanaan sampai dengan evaluasi kegiatan. Kelompok mitra tidak hanya sebagai obyek kegiatan, tetapi juga sebagai pelaku kegiatan, sedangkan Tim Pelaksana hanya bertindak sebagai fasilitator dan motivator. Komitmen sinergi antara Tim Pengabdi dan mitra sangat penting untuk keberhasilan capaian target kegiatan.

\section{HASIL KEGIATAN}


Kegiatan ini diawali dengan penyampaian materi tentang konsep pembelajaran bahasa Inggris bagi anak usia dini atau English for young Learner oleh Drs. Kamaluddin Y., M.A., Ph.D. (Gambar 1). Dilanjutakan dengan materi tentang pembelajaran bahasa Inggris melalui lagu oleh Khusnul Khotimah, S.Pd., M.Pd. Materi berikutnya adalah tentang pembelajaran bahasa Inggris melalui permainan yang disampaikan oleh Atri Dewi Azis, S.Pd., M.Hum.

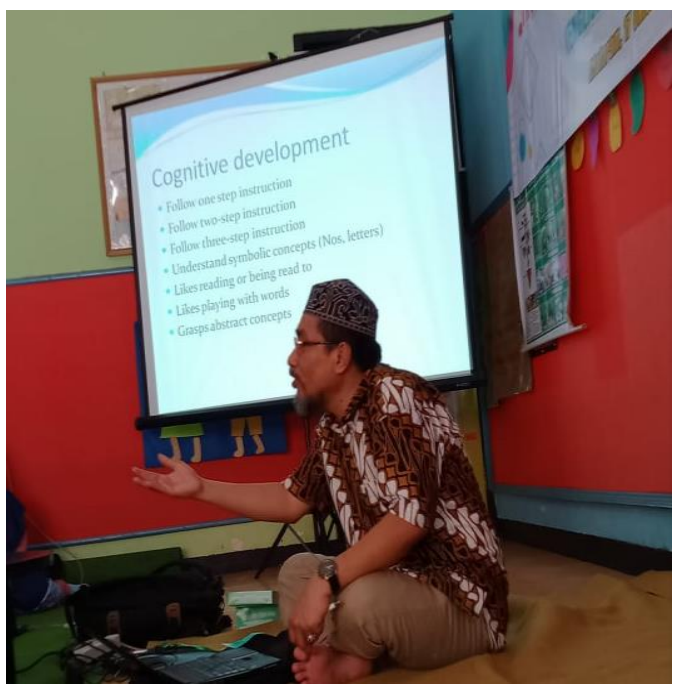

Gambar 1. Pemaparan materi konsep English for young Learner oleh narasumber.

Dalam pemamparannya Drs. Kamaluddin Y., M.A., Ph.D menjelaskan bahwa Perkembangan dan proses belajar bahasa anak khususnya di usia dini terjadi dalam suatu konteks sosial, yaitu dalam komunitas yang penuh dengan orang yang berinteraksi dengan anak tersebut. Orangorang yang ada di sekitar anak-anak ini penting perannya dalam membantu mereka untuk belajar menggunakan bahasa. Anak merupakan pembelajar aktif yang hidup di antara orang lain sejak masih bayi. Melalui interaksi sosial, orang dewasa bertindak sebagai perantara dengan dunia sekitar anak. Dengan bantuan orang dewasa, anakanak dapat melakukan dan memahami lebih banyak daripada kalau mereka belajar seorang diri. Lebih lanjut dijelaskan bahwa anak-anak adalah peniru ulung. Mereka memiliki kemampuan luar biasa dalam mengamati peristiwa yang terjadi di sekitar mereka.

Pada umumnya, anak-anak mampu menirukan apa yang mereka tangkap dari lingkungan sekitar mereka. Apa yang dikatakan dan dilakukan oleh guru atau orang tua, tanpa disadari akan ditiru oleh anak. Anak belajar dari apa yang ia lihat dan ia dengar. Apa yang guru atau orang tua lakukan, baik itu gerakan, kata-kata atau emosi, semuanya menjadi sarana belajar bagi anak.

Nara sumber kedua memaparkan materi tentang pembelajaran bahasa Inggris melalui lagu (Gambar 2). Proses pembelajaran bahasa Inggris memerlukan strategi yang tepat dan efektif. Kemampuan seorang guru dalam mengkreasikan proses pembelajaran yang menarik dan menyenangkan sangat mempengaruhi keberhasilan pembelajaran bahasa Inggris pada anak usia dini. Di samping itu, seorang guru harus bisa menciptakan suasana kelas yang relaks, sehingga siswa bisa menerima materi dengan baik tanpa terbebani. $\mathrm{Di}$ antara strategi mengajar bahasa Inggris untuk anak usia dini yang bisa dilakukan oleh para guru adalah menggunakan lagu.

Bernyanyi adalah suatu pendekatan pembelajaran secara nyata yang mampu membuat anak senang dan bergembira. Anak diarahkan pada situasi dan kondisi psikis untuk membangun jiwa yang bahagia, senang menikmati keindahan. Demikian pemaparan yang disampaikan oleh Khusnul Khotimah, S.Pd., M.Pd. 


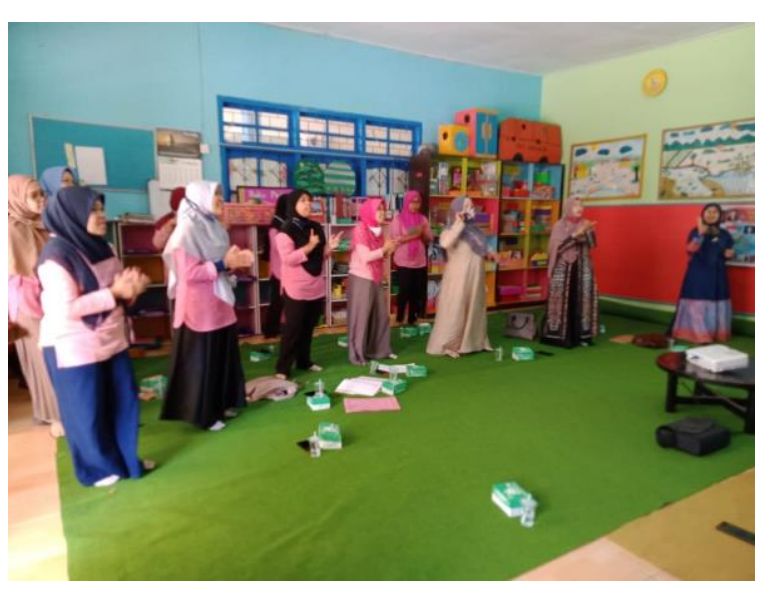

Gambar 2. Praktek menyanyikaan lagu berbahasa Inggris.

Atri Dewi Azis, S.Pd., M.Hum dalam pemaparannya menjelaskan bahwa pada setiap anak usia dini, bermain itu adalah belajar karena memang dunia anak adalah dunia bermain. Dengan bermain, anak dapat belajar dengan baik dan menyenangkan tentang berbagai hal kehidupan sehari-hari. Dengan permainan, kita sebagai guru atau orang tua bisa memasukkan unsur-unsur pendidikan didalamnya. Bermain itu penting bagi anak, karena bermain merupakan bagian sangat penting dari proses tumbuh kembang anak. Melalui kegiatan bermain, anak akan belajar berbagai hal tentang kehidupan sehari-hari. Anak akan mendapatkan pengalaman yang berkaitan dengan lingkungannya, baik lingkungan sosial budaya, lingkungan sosial ekonomi, maupun lingkungan fisik atau alam, yang sangat bermanfaat untuk meningkatkan kemampuan berbahasa, berpikir, bersikap, bergaul, berkarya, dan sebagainya.

Dalam permainan anak mencurahkan perhatian, perasaan, dan pikiran pada proses bermain serta sifat dan bentuk alat permainannya. Dengan demikian, anak-anak akan belajar mengenali dan menjajaki lingkungannya. Beberapa permainan dapat dimainkan untuk mengembangkan kosa kata atau mengembangkan kemampuan bahasa Inggris di usia dini yaitu permainan whisper race, hide and seek, what's missing, Simon says, I see, dan permainan take a number.

\section{KESIMPULAN DAN SARAN}

\section{Kesimpulan}

Pelatihan tentang pengembangan permainan dan lagu berbahasa Inggris telah berhasil dilakukan. Pemahaman yang baik kepada peserta tentang hakikat pembelajaran bahasa Inggris bagi anak usia dini. Pembelajaran bahasa Inggris ketika ditanamkan lebih dini, hasilnya akan semakin baik dengan tetap memperhatikan konsep-konsep dasar perkembangan kemampuan berbahasa anak. Proses pembelajaran bahasa Inggris harus menggunakan metode belajar yang menyenangkan untuk anak. Metode mengajar yang menyenangkan merupakan faktor eksternal yang harus disiapkan oleh guru ketika anak belajar bahasa Inggris. Metode yang efektif dalam pembelajaran bahasa Inggris yaitu bernyanyi dan bermain. Belajar bahasa Inggris dengan bernyanyi atau bermain merupakan kegiatan yang dapat membawa kesenangan tersendiri bagi anak dan dapat mengembangkan imajinasi dan rasa percaya diri anak.

\section{Saran}

Perkembangan

kemampuan berbahasa anak usia dini sangat berkaitan dengan perkembangan berbicara. Untuk meningkatkan kemampuan berbahasa Inggris anak PAUD/TK, maka perlu dikenalkan metode mengajar melalui permainan dan lagu berbahasa Inggris, agar semakin kaya kemampuan berbahasanya. Semakin kaya kemampuan berbahasa membuat anak semakin percaya diri untuk berbicara.

\section{UCAPAN TERIMA KASIH}

Tim kegiatan menyampaikan terima kasih kepada Rektor Universitas Mataram atas dukungan dana yang telah diberikan melalui skim PNBP tahun Anggaran 2020, sehingga kegiatan ini dapat terlaksana dengan baik. Begitu pula kepada seluruh 
pihak-pihak yang telah membantu kegiatan pengabdian ini disampaikan terima kasih.

\section{DAFTAR PUSTAKA}

Ahmadi, A. 1991. Psikologi Perkembangan Anak. Jakarta: Rineka Cipta.

Aprianti E. 2017. Penerapan pembelajaran BCM (bermain, cerita, menyanyi) dalam konteks perkembangan sosial emosional anak usia dini di Kober Baiturrohim Kabupaten Bandung Barat. Tunas Siliwangi, 3(2): 195-211.

Bjorklund, D.F. 2005. Children's Thinking, Cognitive development and Individual deferences. Belmont: Thomson Learning.

Cole, M., and Sheila R.C. 2001. The Development of Children. New York: Worth Publishers.

John, W. S. 2007. Perkembangan Anak. Jilid 1 Edisi kesebelas. Jakarta : PT. Erlangga.

Handayani, A. 2019. Anak Cerdas Lewat Bermain. Majalah Psikologi Plus, 3(10): 23-30.

Langeveld, M.J. 1980. Pedagogik Teoritis dan Sistematis, Alih Bahasa: Firmansyah. Bandung: 